岡永 覚

\title{
Re-evaluation of Human Masticatory Movements : Treatment of Temporomandibular Disorder (TMD) with Physiotherapy including Chiropractic Procedures.
}

Satoru Okanaga

\begin{abstract}
Masticatory movements are complicated movements based upon individual habits. In dental practice, mandibular movements have routinely been reproduced using an articulator. At present, various kinds of adjustable articulators are available which claim to be able to reproduce individual mandibular movements.

However, there are many indecations that it is extremely difficult to reproduce individual matiscatory function on articulator.

This presentation investigates the reasons for this difficulty by undertaking clinical case studies of patients with temporomandibular disorder (TMD) treated with physiotherapy, including chiropractic procedures.
\end{abstract}

歯科医学の分野において，長年に渡り咬合器を使い口腔外でヒトの下顎運動を再現する 研究がなされてきたが，咬合器上にヒトの生理機能を再現するのは難しく，臨床上トラブ ルが多いという指摘もある。

筆者の経験でも，顎関節症患者に扔いて生理的下顎運動を咬合器上に再現するのはきわ めて難しい、顎関節症患者の多くは，顔面㧍よび頸・背部の筋肉の緊張と圧痛を認め，筋 肉間のバランスが崩れ，下顎の運動障害を抱えている。そのような患者に対して，スプリ ントや咬合調整などの治療のほかにカイロプラクティックなどの理学療法を併用すると, 下顎運動が変化してくる。このように下顎位が定まらない患者において, 咬合器上に生理 的下顎運動を再現することは無理である。まず，筋肉の緊張を取り除き，筋肉間のバラン スを回復させることから始め，下顎運動の安定化を確認してから下顎の位置を決めたうえ で咬合器に下顎の歯型模型を付着しないと，咬合器上に生理的下顎運動を再現することは できない.

Key words：咀嚼運動，下顎運動，咬合器，顎関節症 


\section{緒言}

咀嚼運動は，上顎を固定して，下顎が上下することに よって上下顎の歯牙が噛み合い運動を繰り返す運動である が，上下 (開閉), 前後・左右側方の各運動が混合され, 唇，煩，舌なども補助的に働く複雑な運動である。また， 噛み始めは随意運動と考えられ，大脳皮質四野の下端近く にその部位が指摘されているが，その後は半ば付随意的な 反射運動としての要素が多い1).そして歯科医学の分野で は, 長年に渡り，咬合器を使ってヒトの下顎運動を口腔外 で再現し，咬合の診断および治療に役立てる研究がなされ てきた．現在では調節性咬合器により，個々のケースに応 じた下顎運動の再現が可能になった ${ }^{1) 〜 2)}$.

しかし, 実際の臨床では, 咬合器上にヒトの生理的な機 能を再現することが難しく，治療によるトラブルも多い. 筆者のもとにも，トラブルの相談が多く寄せられてい る ${ }^{3)}$-5).なぜこのようなことが起きるのだろうか. はたし て, 咬合器上にヒトの下顎運動を再現する方法に問題はな かったのか. 今回は顎関節症の症例研究を通して，その問 題について検証してみたい.

\section{症例報告}

今回, 紹介する臨床データは岡永歯科において 3 カ月以 上継続して顎関節症の治療を受けた患者のカルテから無作 為に 40 症例を抽出したものである ${ }^{6}$.

\section{1. 性別・年齢}

40 症例の性別，年齢構成は，以下の通りである ${ }^{6)}$.

\section{(1)性別}

男性 $(15$ 人 $\cdots 37.5 \%)$ ，女性 $(25$ 人 $\cdots 62.5 \%)$.

\section{(2)年齢}

20 歳未満 $(2$ 人 $\cdots 5 \%), 20$ 歳台 $(15$ 人 $\cdots 37.5 \%), 30$ 歳台 $(14$ 人 $\cdots 35 \%), 40$ 歳台 $(6$ 人 $\cdots 15 \%), 50$ 歳台 $(2$ 人 $\cdots 5 \%), 60$ 歳以上 $(1$ 人 $\cdots 2.5 \%)$.

以上をほかの顎関節症に関する疫学調査デー夕と比較し たところ，おおむね同様の傾向が認められたので, 症例に 偏りがないと判断したプー8).

\section{2. 問診結果}

40 症例の問診結果は以下の通りである。問診は，問診 表の記載内容をもとに自覚症状，既往歴および日常の生活 習慣（日常生活で頻度の多い動作）について確認した ${ }^{6)}$. (1)局所症状

口を開ける時に途中で引っかかる感じがする（20人… $50 \%)$ ，口の開閉時に音がする $(16$ 人 $\cdots 40 \%)$, 口が開け
にくい $(15$ 人 $\cdots 37.5 \%)$ ，口を開ける時に途中でずれる感 じがする $(14$ 人 $\cdots 35 \%)$ ，硬いものを噛むと疲れる（11 人 $\cdots 27.5 \%)$ ，大きく口を開ける時に痛みが走る（11人… $27.5 \%)$ ，口の開閉がスムーズにいかない（10人 $\cdots 25 \%)$, 㚘頁の粘膜をよく噛んでしまう（7人 $\cdots 17.5 \%)$, 口内炎が よくできる $(7$ 人 $\cdots 17.5 \%)$ ，長く話すと疲れる（3人 $\cdots$ $7.5 \%)$.

\section{(2)姿勢の異常}

前かがみになっている $(12$ 人 $\cdots 30 \%)$ ，一方の肩が傾い ている $(11$ 人 $\cdots 27.5 \%), \mathrm{X}$ 脚あるいは $\mathrm{O}$ 脚である（10人 $\cdots 25 \%)$, 頭が左右一方に傾いている (8人 $\cdots 20 \%)$, まっすぐに立てない $(3$ 人 $\cdots 7.5 \%)$ ，身体を静止できない (1 人 $\cdots 2.5 \%)$.

\section{(3)既往歴}

歯を食いしばることが多い（13人 $\cdots 32.5 \%) ，$ 歯並びは 悪い方である $(12$ 人 $\cdots 30 \%)$ ，親知らずがある（12人… $30 \%)$, 昔から歯が悪い方である $(11$ 人 $\cdots 27.5 \%)$, 最近 歯の治療をした $(10$ 人 $\cdots 25 \%)$ ，片方のみで噛んでいる $(9$ 人 $\cdots 22.5 \%)$, 歯列矯正をしたことがある $(8$ 人 $\cdots 20 \%)$, 口臭がある（7人 $\cdots 17.5 \%) ，$ 歯が抜けたままになってい る $(5$ 人 $\cdots 12.5 \%)$, 歯と歯の間がすいている $(4$ 人 $\cdots$ $10 \%)$, 受け口である $(4$ 人 $\cdots 10 \%)$, 出っ歯である（4人 $\cdots 10 \%)$ ，八重歯がある $(3$ 人 $\cdots 7.5 \%)$, 乱ぐい歯である (3人 $\cdots 7.5 \%)$, 治療した歯が痛むことがある $(2$ 人 $\cdots 5 \%)$, 歯がグラグラしている $(1$ 人 $\cdots 2.5 \%)$ ，歯ぐきから出血し ている $(1$ 人 $\cdots 2.5 \%)$.

\section{(4) 全身症状}

首筋が凝る $(31$ 人 $\cdots 77.5 \%)$, 肩が凝る $(26$ 人 $\cdots 65 \%)$, 目が疲れる $(24$ 人 $\cdots 60 \%)$, 頭痛がする $(15$ 人 $\cdots 37.5 \%)$, 目の奥が痛むことがある $(12$ 人 $\cdots 30 \%)$ ，背中が痛む（11 人 $\cdots 27.5 \%)$ ，立ちくらみをおこすことがある（9人… $22.5 \%)$ ，胃腸の調子が悪い $(8$ 人 $\cdots 20 \%)$ ，手足のしびれ がある $(7$ 人 $\cdots 17.5 \%)$ ，めまいがする（7人 … $17.5 \%)$, 耳鳴りがする $(6$ 人 $\cdots 15 \%)$ ，息切れがすることがある（6 人 $\cdots 15 \%)$ ，息がつまる $(5$ 人 $\cdots 12.5 \%)$ ，声がかれる（5 人 $\cdots 12.5 \%)$, 扁桃腺が弱い $(5$ 人 $\cdots 12.5 \%)$, いびきをか く $(4$ 人 $\cdots 10 \%)$, 動悸がある $(3$ 人 $\cdots 7.5 \%)$.

\section{(5)職場や家庭での頻度の多い動作}

パソコンの使用 $(18$ 人 $\cdots 45 \%)$ ，デスクワーク（9人 $\cdots$ $22.5 \%)$, 自動車の運転 (4人 $\cdots 10 \%)$, 重たい物を持つ $(4$ 人 $\cdots 10 \%)$, 立ち仕事 $(3$ 人 $\cdots 7.5 \%)$, 反復動作（1人 $\cdots 2.5 \%)$.

以上をほかの顎関節症に関する疫学調査デー夕と比較し たところ，おおむね同様の傾向が認められたので，症例に 


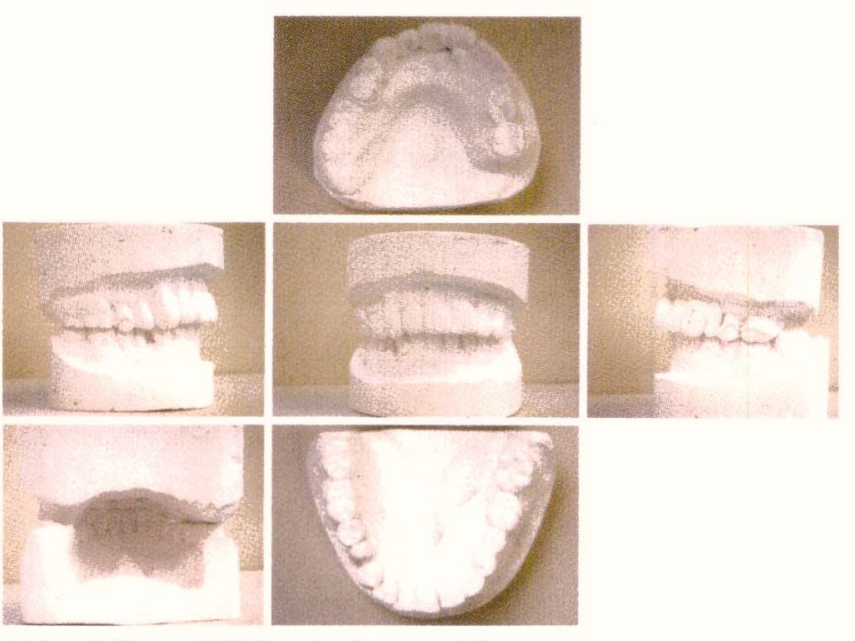

図 1 症例 1 の初診時スタディーモデル.

偏りがないと判断したプー8).

ここで興味深かったことは, 上部澒椎（環軸関節）のサ ブラクセーション (亚脱臼) を疑わせる病状が多かったこ とである。

首筋の凝り $(31$ 人 $\cdots 77.5 \%)$ ，口が開けにくい（15人 人 $37.5 \%)$, 目の奥が痛むことがある $(12$ 人 $\cdots 30 \%)$, 背中 が痛む $(11$ 人 $\cdots 27.5 \%)$, 頭が左右一方に傾いている $(8$ 人․ $20 \%)$ ，めまいがする $(7$ 人 $\cdots 17.5 \%)$.

\section{3. 診査結果}

以上の問診結果をもとに診査を行った. 40 症例の診査 結果は, 以下の通りであった6.

\section{(1) 下顎運動}

·最大開口量

$2 \mathrm{~cm}$ 未満 $(1$ 人 $\cdots 2.5 \%), 2 \mathrm{~cm}$ 台 $(1$ 人 $\cdots 2.5 \%), 3 \mathrm{~cm}$ 台 $(10$ 人 $\cdots 25 \%), 4 \mathrm{~cm}$ 台 $(18$ 人 $\cdots 45 \%), 5 \mathrm{~cm}$ 台 $(9$ 人 $\cdots 17.5 \%)$, $6 \mathrm{~cm}$ 以上 $(1$ 人 $\cdots 2.5 \%)$.

\section{・下顎運動時の偏位}

40 人中 12 人 $(30 \%)$ に偏位が認められた。右偏位が認 められた $\cdots 8$ 人 $(20 \%)$, 左偏位が認められた $\cdots 4$ 人 $(10 \%)$.

\section{・下顎運動時の関節杂隹音}

40 人中 34 人 $(85 \%)$ に関節雑音が認められた. 左右の 顎関節に認められた $\cdots 15$ 人 $(37.5 \%)$, 右の顎関節のみ認 められた $\cdots 12$ 人 $(30 \%)$, 左の顈関節のみ認められた $\cdots 7$

人 $(17.5 \%)$.

\section{. 下顎運動時の疼痛}

40 人中 9 人 $(22.5 \%)$ に疼痛が認められた. 前方運動時 に疼痛が認められた $\cdots 4$ 人 $(10 \%)$, 右側方運動時に疼痛 が認められた $\cdots 5$ 人 $(12.5 \%)$, 左側方運動時に疼痛が認

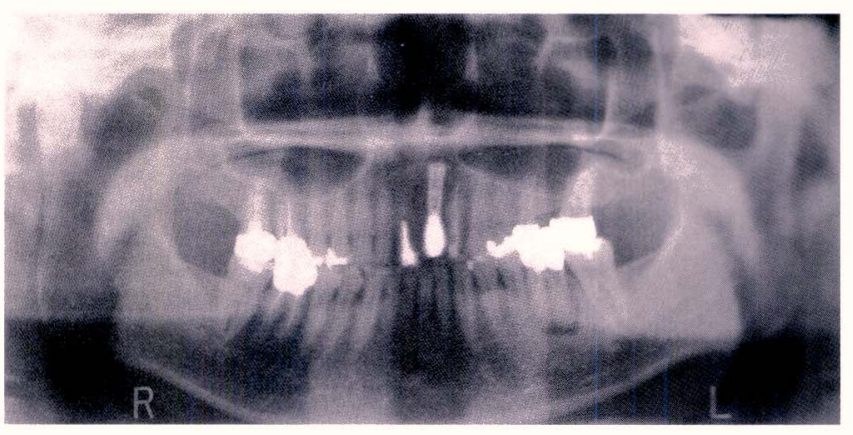

図2 症例2の初診時パノラマX線写真.

められた $\cdots 6$ 人 $(15 \%)$.

・下顎運動時の下顎頭の動き

閉口時と開口時をX線写真（パルマー法）で比較した. 顆路に沿った下顎頭の移動が認められた $\cdots 40$ 人 $(100 \%)$, 下顎頭の移動が認められなかった $\cdots 0$ 人 $(0 \%)$.

\section{(2) 筋肉の緊張状態}

- 筋肉の圧痛

40 人中 40 人 $(100 \%)$ に圧痛が認められた。胸鎖乳突 筋の圧痛右 $\cdots 2$ 人 $(5 \%)$ 左 $\cdots 36$ 人 $(90 \%)$ 左右 $\cdots 2$ 人 $(5 \%)$ ，僧帽筋の圧痛 右 $\cdots 2$ 人 $(5 \%)$ 左 $\cdots 35$ 人 $(87.5 \%)$ 左右 $\cdots 3$ 人 $(7.5 \%)$, 側頭筋の圧痛 右 $\cdots 3$ 人 $(7.5 \%)$ 左 $\cdots 7$ 人 $(17.5 \%)$ 左右 $\cdots 0$ 人 $(0 \%)$, 咬筋の圧痛 右 $\cdots 6$ 人 $(15 \%)$ 左 $\cdots 7$ 人 $(17.5 \%)$ 左右 $\cdots 0$ 人 $(0 \%)$.

- 肩の高さ

40 人中 37 人 $(92.5 \%)$ に肩の高さの差異が認められた. 右の肩が高い…1 人 $(2.5 \%)$, 左肩が高い... 36 人 $(90 \%)$.

(3) 脍椎の状態

40 人中 40 人 $(100 \%)$ に脊椎・骨盤にサブラクセー ションが認められた。 頚椎のみにサブラクセーションが認 められた $\cdots 0$ 人 $(0 \%)$, 胸椎のみにサブラクセーションが 認められた $\cdots 0$ 人 $(0 \%)$, 腰椎・骨盤のみにサブラクセー ションが認められた $\cdots 0$ 人 $(0 \%)$, 頚椎・胸椎にサブラク セーションが認められた $\cdots 19$ 人 $(47.5 \%)$, 胸椎・腰椎と 骨盤にサブラクセーションが認められた $\cdots 0$ 人 $(0 \%)$, 頝 椎・腰椎と骨盤にサブラクセーションが認められた $\cdots 0$ 人 $(0 \%)$, 澒椎 ·胸椎と腰椎 ·骨盤にサブラクセーションが 認められた $\cdots 21$ 人 $(52.5 \%)$.

\section{(4) 歯型模型}

40 人中 40 人 $(100 \%)$ に何らかの異常が認められた。 咬耗 $\cdots 35$ 人 $(75 \%)$, 叢生歯 $\cdots 14$ 人 $(35 \%)$, 反対咬 


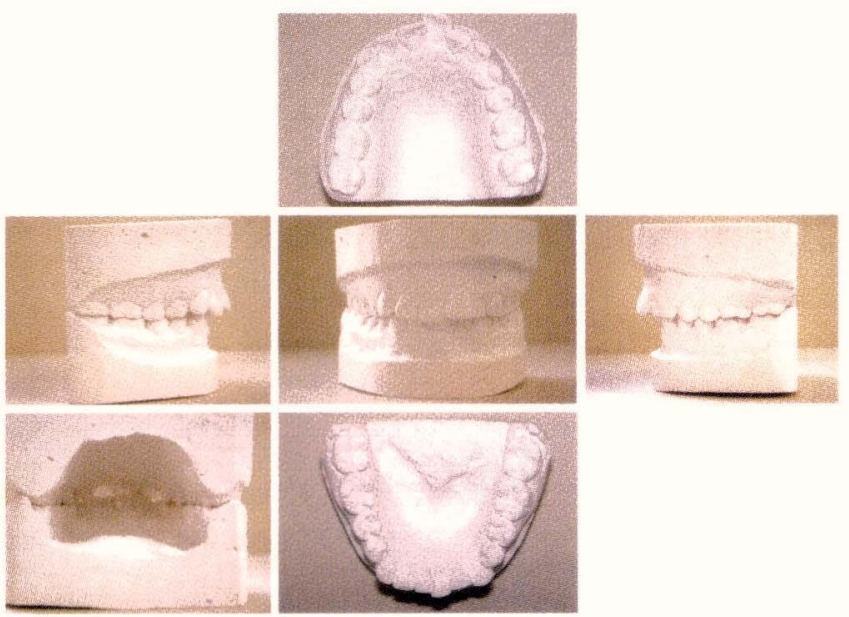

図3 症例 3 の初診時スタディーモデル

合 $\cdots 1$ 人 $(2.5 \%)$.

(5)ストレスの状態

交流分析の結果， 40 人中 9 人 $(22.5 \%)$ に何らかの問題 が認められた。

以上をほかの顎関節症に関する疫学調査データと比較し たところ，脊椎の状態を除きおおむね同様の傾向が認めら れたので，症例に偏りがないと判断したプー8).

参考のため，印象に残った代表的な症例を数例紹介す

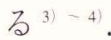

\section{歯科補緅治療に起因する症例}

症例 1）他院にてクラウン, 床義歯をセット後にTMJの 不調を訴えて来院した症例，顎関節症の治療後，当院にて 歯科補綴治療をやり直した (図 1 $)^{3}$.

症例 2) 他院にて治療後, 頭痛, 歯痛（下顎左側第一大 臼㐘）を訴えて来院した症例。「頭がターミネーターのよ うになる」らしい. 交流分析の結果, 精神的要因の関与が 疑わ机，歯ぎしりが激しい。下顎左側大一大臼㐘の苗痛は， 歯ぎしりによる咬合性外傷が疑われる(図2) ${ }^{3}$.

矯正歯科治療に起因する症例

症例 3）他院にて小目歯を抜歯して歯科矯正治療をした 後，TMJの不調を訴之て来院した症例（図 3） ${ }^{3)}$. 咬合治療に起因する症例

症例 4）激しい歯軋りによる頭痛を訴えて来院した症例 (図4).著しい咬耗による低位咬合が認められた(図4右)。 他院では，低位咬合を放置したまま治療したようだ。上下 顎スプリント（図４中央）で咬合を挙上した後，オーラ ルリハビリテーションを行った (図 4左) ${ }^{4)}$.

\section{手技療法に起因する症例}

他院にて TMJの手技療法を受けているにも係わらず， 開口障害や咬合障害を訴えて来院する症例 ${ }^{3}$.

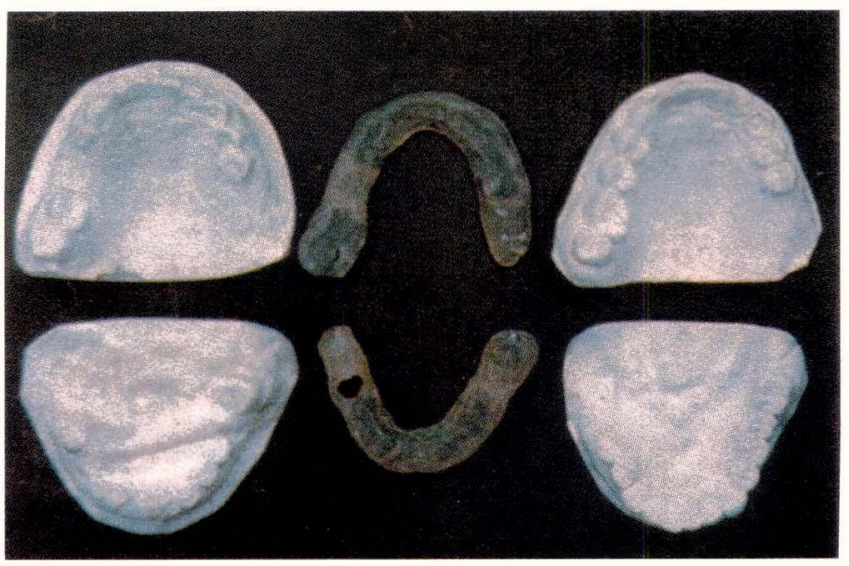

図4＼cjkstart症例 4のスタディーモデルとスプリント

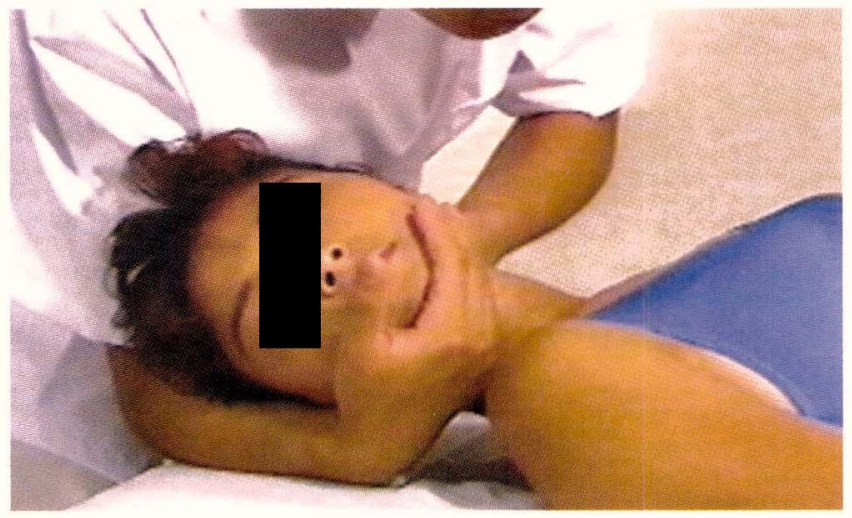

図 5 マスターサービカル。

\section{治療法}

\section{1. 理学療法}

40 人中 40 人に対して, 以下の理学療法を行った9-10). (1)カイロプラクティック

以上の診査結果にもとづき, 術前マッサージの後, サブ ラクセーションに対して春椎矯正を行った9゙10).

矯正テクニックは，以下のようなディバーシィファイ ド・テクニックを使用した ${ }^{11)}$-18).

頚椎…ーハンド・サービカル・エクステンションマス ターサービカル (図 5), 胸椎‥シィッティング・ソラ シック・エクステンション：フルネルソン (図 6), 腰椎 ・イリオ・デルロイド，骨盤‥イリオ・デルロイドイシ アルデルロイドペルビスデルロイド.

(2)赤外線療法・低周波治療

顔面部に赤外線を照射した後，圧痛点を参考にして低周 波治療を行った（図７，8）。圧痛点は筋肉の起始端が多 く，ツボやトリガーポイントと一致している場合が多い. よって，そ机らを参考にして通電するとよい199. 


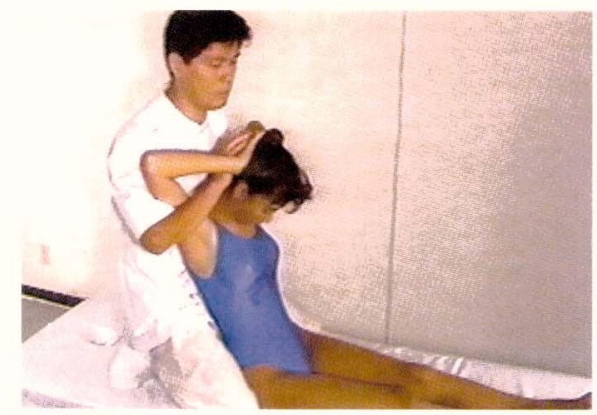

図6 シッティング・ソラシック・エクステン ション: フルネルソン.

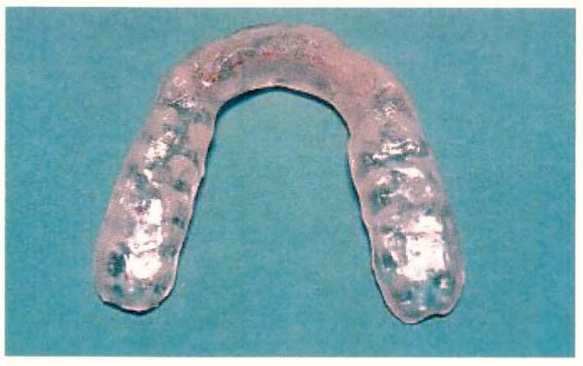

図9 右側方移動型.

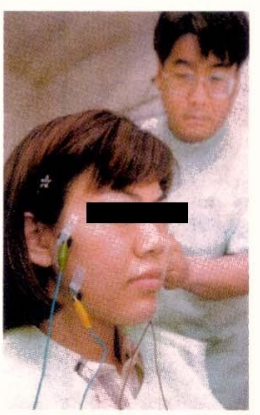

図 7 低周波治療。

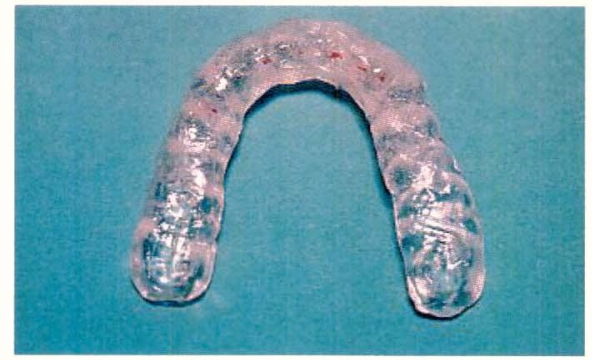

図 10 前方移動型.

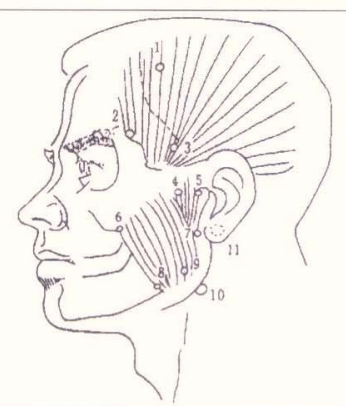

1. 頭維, 2. 糸竹空,

3. 太陽，4.下関，

5. 恥宮, 6. 観髎,

7. 治壟四, 8.大迎,

9. 㚘貣車, 10. 下顎角內側,

11. 耳の後ろ・関節頸後縁

\section{(3) 筋エネルギーテクニック}

顔面部に赤外線治療・低周波治療を行った後，TMJに対 して筋エネルギーテクニック（MET）を行った。開口運動， 閉口運動，側方運動に対して行った201ー22.

※カイロプラクティックにも顎関節の矯正テクニックが あるが，ほとんど筋エネルギーテクニックを用いてい る ${ }^{23}-28$.

\section{2. 歯科治療}

すべての患者に対して，理学療法と並行して以下のよう な流れで歯科治療を行った。

スプリント $\cdots 40$ 人 $(100 \%) ，$ スプリントの治療後咬合 調整中 $\cdots 10$ 人 $(25 \%)$ ，スプリント・咬合調整の治療後補 綴治療 $\cdots 1$ 人 $(2.5 \%)$, スプリント・咬合調整の治療後歯 列矯正中 $\cdots 2$ 人 $(5 \%)$.

\section{3. 心理療法}

交流分析の結果に問題があった 9 人中の 4 人に対して, 以下の心理療法を併用した。

自律訓練法 $\cdots 4$ 人 $(10 \%)$, 薬物療法（トランキライ ザー) $\cdots 3$ 人 $(7.5 \%)$.

\section{治療経過}

\section{1. 治療期間}

40 人の治療期間は，以下の通りである.

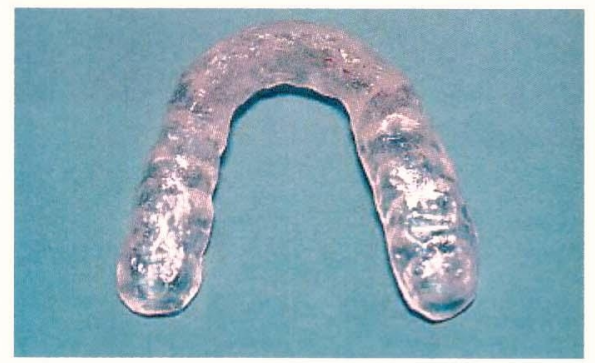

図 11 左側方移動型
3 力月 $\cdots 7$ 人 $(17.5 \%), 4$ 力月 $\cdots 4$ 人 $(10 \%), 5$ 力月 $\cdots 3$ 人 $(7.5 \%), 6$ 力月 $\cdots 3$ 人 $(7.5 \%), 7$ 力月 $\cdots 2$ 人 $(5 \%), 8$ 力月 $\cdots 0$ 人 $(0 \%), 9$ 力月 $\cdots 5$ 人 $(12.5 \%)$, 10 力月 $\cdots 4$ 人 $(10 \%), 11$ 力月 $\cdots 3$ 人 $(7.5 \%), 12$ 力月. 7 人 $(17.5 \%) 13$ 力月以上 $\cdots 2$ 人 $(5 \%)$.

\section{2. 治療経過}

40 人の治療経過は以下の通りである。ほとんどのケー スで，筋肉の緊張が緩和され，臨床的に病状の軽快が認め られた。

臨床的に病状が軽快した症例‥3 39 人 $(97.5 \%)$ ，臨床的 に病状が軽快しなかった症例 $\cdots 0$ 人 $(0 \%)$ ，治療が中断し， 予後判定ができなかった症例 $\cdots 1$ 人 $(2.5 \%)$.

それにともない下顎位が変化し，下顎運動が変化して いった。スプリントを調整すると，下顎位の変化がよく解 る。下顎位の変化の仕方は, 右側方移動型, 前方移動型, 左側方移動型の 3 パターンになった（図9-図11).

\section{結論}

顎関節症の患者に対してカイロプラクティックなどの理 学療法を併用した歯科治療を行ったところ，すべての症例 で下顎位が変化し，スプリントの調整が必要となった。下 顎位が変化するとヒンジアキシスも変わるので，咬合器上 の正確な位置に下顎模型を付着することができない。した がって，このような状態下で咬合器上に生理的な下顎運動 
を再現するのは無理であろう．

しかし，すべての患者において下顎位が定まらないので はない. 少なくとも，治療を続けた $25 \%$ の患者がスプリ ントの調整が必要のない状態に回復している。この段階の 患者は，筋肉の緊張が取り除かれ，筋肉間のバランスが回 復している状態で，下顎運動も安定している。このような 状態になると，咬合調整が可能になるだけでなく，ヒンジ アキシスを参考に下顎模型を咬合器に付着して生理的な下 顎運動を再現することができるようになる。

\section{考察}

咬合器中心の咬合論は，筋肉間のバランスにより TMJ 内において下顎頭の位置が容易に変わりうるという概念を 欠いているように思えてならない. 顎関節症の患者の多く は, 顔面や頚・背部などの筋肉が緊張して圧痛が認められ， 筋肉間のバランスが 崩れ，運動障害が認められる状態で ある。したがって，下顎が緊張している筋肉の側に引っ張 られ，下顎頭の位置がわずかに変位していたとしても何ら
不思議なことではない。また，開口筋が下顎の後下方に向 かって走り，ほとんど舌骨に終わり，下顎骨から下方に進 む筋肉が主に胸骨に，そして一部が肩甲骨に終わっている ことを考えると，肩甲部および䅡部の筋肉のバランスが崩 れると, 舌骨が不安定となり下顎運動に影響をおよぼすこ とが考えられる．それを示唆する現象は，顎関節症の患者 を治療していく過程で観察される．顎関節症の患者にカイ ロプラクティックなどの理学療法を併用した治療を続け, 筋肉をリラックスさせバランスのとれた状態にしていく と，下顎運動がダイナミックに変化していく．その過程で， 下顎頭の位置およびヒンギアキシスもダイナミックに変化 していく.

以上より, 咬合器上に生理的機能を再現するためには, 生体において下顎運動が安定し，再現性がある状態下で咬 合採得しなければならないことは明らかである。従来から 行われてきた骨学などの解剖学的アプローチにはおのずと 限界があり，筋肉などの状態にも配慮した解剖・生理学的 アプローチへの飛躍が求められよう.

\section{参考文献}

1）川和忠治，他：生理的咬合へのアプローチ．医歯薬出版 (東京), 13-16, 1992.

2）上条擁彦：四説口腔解剖学 2 筋学. アナトーム社 (東京), 67-76, 1979.

3）岡永 覚：顎関節症患者からの訴えに耳を傾けて．補綴臨 床 36, 1 ：98-107, 2003.

4）浜野雪江，他：ストレス歯痛に新療法，アエラ，29：53$56,2002$.

5）林 義人：21 世紀病「顎関節症」，アサヒ芸能 58（11）, 徳間書店 (東京)，156，2003.

6）岡永 覚: 岡永歯科における顎関節症治療の現状について. 千葉県歯科医学誌, 1 : 35-36, 2003.

7）正司善信, 他：臨床家が行う顎関節症のマネージメント. 医歯薬出版 (東京) 6-13, 2001.

8）小林俊三，他：顎関節症のすべて。デンタルダイヤモンド (東京)，30-46，1982.

9）岡永 覚：顎関節症の理学療法に関する私見. 日本顎咬合 学会誌咬み合わせの科学，22（2）：197-201，2001。

10）岡永 覚: 顎関節症の理学療法. 第 15 回保団連医療研究 集会記録集，全国保険医団体連合会（東京），221-224， 2001.

11）竹谷内宏明, 他：脊柱・骨盤のテクニック。科学新聞社 (東京), 2003 .

12）鈴木正教：カイロプラクティック概論. たにぐち書店（東 京), 133-235, 1995.

13）グラント・レイド：カイロプラクティックマニュアル. 医 道の日本社 (横須賀), 2003.

14）山根 悟：図と写真で学ぶカイロプラクティック教本 体幹 編. 医道の日本社（横須賀），2002.

15）小倉 毅：症状別カイロプラクティック ハンドブック . 科 学新聞社 (東京), 14-62, 2004.

16） Diane Lee，他：脊柱・骨盤のマニュアルセラピー。医歯薬 出版 (東京), 1990.

17）キム・クリステンセン：クリニカルカイロプラクティック テクニック．医道の日本社（横須賀），41-72，1994.

18）大川 泰：入門カイロプラクティック。たにぐち書店（東 京), 69-92, 2001.

19）四川医学院：口腔顔面外科学（第 1 版）. 四川人民出版社 (中国), 284-287, 1974.

20）L.Chaitow：軟部組織の診かたと治療。医道の日本社（東 京) 111-114，163-187，1997。

21）中島榮一郎，他：歯科 PNF マニュアル．クインテッセンス 出版 (東京), 2003.

22) Tore L. Hansson, 他 : 頭蓋下顎障害 (CMD) の理学療法. クインテッセンス出版 (東京), 1998.

23）山根 悟：図と写真で学ぶカイロプラクティック教本 四肢 編。医道の日本社（横須賀），230-233，2002.

24）グランド・レイド：カイロプクティックマニュアル 四肢 編。医道の日本社 (横須賀)，91-96，2003.

25）竹谷内宏明，他：四肢のテクニック. 科学新聞社 (東京), $170-173,2002$.

26）小倉 毅：症状別カイロプラクティック ハンドブック．科 学新聞社 (東京), 96-101，2004.

27）キム・クリステンセン：クリニカル カイロプラクティック テクニック，医道の日本社（横須賀），132-136，1998.

28） Freddy M. Kaltenborn : 四肢関節のマニュアル モビリゼー ション, 医歯薬出版 (東京), 217-223, 1995. 